\title{
Effect of Different Concentrations of Biofertilizers on the Growth and Yield of French Bean (Phaseolus vulgaris) Arka Anoop
}

\author{
Madhvi Sharma ${ }^{1 *}$, Kodihally Manchegowda Harinikumar ${ }^{2}$ and Anil Kumar Singh ${ }^{2}$ \\ ${ }^{1}$ School of Biotechnology, Sher-e-Kashmir University of Agricultural Sciences and \\ Technology, Chatha, Jammu,180009, India \\ ${ }^{2}$ Department of Plant Biotechnology, University of Agricultural Sciences, GKVK, \\ Bangalore, 560065, India \\ *Corresponding author
}

Keywords

Biofertilizers, Pseudomonas, Nitrogen, French bean, Yield

Article Info

Accepted:

26 March 2020

Available Online:

10 April 2020

\section{A B S T R A C T}

The investigation was conducted at department of plant biotechnology, University of Agricultural Sciences, GKVK, Bangalore, from Jan to May during Rabi season, 2015 , on sandy loam soil, pH having 5.3 to 5.5 to study the effect of different concentrations of biofertilizers as sources of nutrients along with inorganic fertilizers in French bean under green house conditions with an objective to study growth and yield without degrading soil quality by using various nutrient compositions with varying concentrations. Experimental treatments comprised of (a) three levels of biofertilizer with different combinations and concentrations (9gm each) in five treatments. The experiment was laid out in different five pots randomized with three replications (Kumar et al., 2009) (5). The results indicate that the highest plant height $(48.34 \mathrm{~cm})$ was obtained in treatment $\mathrm{T} 3$ with each 9gm Rhizobium leguminosarum $+9 \mathrm{gm}$ of phosphate solubilizing bacteria, the highest dry weight plant (22.20g), Pods per plant (10.00), Pods per cluster (3.00) and pod yield (71.06 g) Number of leaves per plant (28.83), number of cluster per plant (3.73), seeds per pod (7). Application of combination of $9 \mathrm{gm}$ of Rhizobium leguminosarum $+9 \mathrm{gm}$ of phosphate solubilizing bacteria biofertilizers was proved to be the best possible combination.

\section{Introduction}

The crop productivity is dependent on the availability of sufficient nutrients and this nutritional demand is met by means of mineral fertilizers which are applied to soil at different stages of plant growth (NIIR,
2004)3. The recommendation level of fertilizers is crop and region specific based on the crop variety and inherent nutrient supplying capacity of the soil in which crop is being produced (Pramanik et al., 2014)6. French bean (Phaseolus vulgaris L.) is one of the most important leguminous vegetables in 
India. It is a nutritious vegetable and can be grown extensively because of its short duration and for nutritive values (Broughton et al., 2003)4.

It is a good source of protein, calcium, phosphorus, iron, carotene, thiamine, riboflavin and vitamin C (Afzal et al., 2008) 1. In India, it is grown for tender vegetables, shelled green beans and dry beans (Rajmah).

These plants originated from the Americas but is now cultivated all over the world due to its nutritional and culinary values. French bean is grown as a cash crop by large and small holder farmers (CIAT, 2006)6.

The highest yield is obtained in soils with a PH between 5.3 and 6.0 (Sankhyan et al., (2001)) 9. The use of chemical fertilizers has drained the soil and resulted in the loss of crop productivity (Satti et al., 2010)10.

So to obtain maximum return farmers need to apply eco-friendly bio-fertilizers that play a vital role in the formation of nodules to fix atmospheric nitrogen by symbiotic process in the root system of legume crops making the nutrient available to the plants and due to this culture the rate of use of bio-fertilizers are increasing day by day (Basu et al., 1990)

2. Biofertilizers are carrier-based inoculants containing cells of efficient strains of specific microorganisms (namely bacteria) used by farmers for enhancing the productivity of the soil by fixing atmospheric nitrogen or by solubilizing soil phosphate or by stimulating plant growth for synthesis of growth promoting substances and play a main key role for selective adsorption of immobile $(\mathrm{P}$, $\mathrm{Zn}, \mathrm{Cu}$ ) bacteria secrete growth substances and secondary metabolic, which contribute to seed germination and plant growth (Rao et al., 1982) 8. In large sense, the term may be used to include all organic resources (manure) for plant growth which are rendered in an available form for plant absorption through microorganisms or plant associations or interactions (Singh et al., 2009) 11. Keeping the views of the above aspects the present research work was, therefore, undertaken to find out the response of French bean to biofertilizers, $\mathrm{N}: \mathrm{P}: \mathrm{K}$, and their different combination and concentrations treatments under controlled condition in the green house at department of plant biotechnology, University of Agricultural Sciences, GKVK, Bangalore, from Jan to May 2015.

\section{Materials and Methods}

The experiment was carried out at the department of plant biotechnology, University of Agricultural Sciences, GKVK, Bangalore, from Jan to May during Rabi season, 2015, on sandy loam soil, $\mathrm{pH}$ having 5.3 to 5.5. Experimental treatments comprised of three levels of biofertilizer (Rhizobia, Pseudomonas and PSB) with different combinations and concentrations (9gm each) in five treatments (T1, T2, T3, T4, T5) with three set of replications (R1, R2, R3) (Table 1). Inorganic fertilizers 9gm (N:P:K) which are widely used in agriculture were used as materials (Kumar et al., 2009)

5. Method of cultural operation was adopted as per recommended practices. And observations were recorded mainly on growth (germination count, plant height, number of leaves, no. of pods per plant, branches per plant, dry weight of plant, cluster per plant) and yield (no. of seed per pod, pods per plant, pods per cluster, pod length, pod yield).

\section{Data analysis}

Statistical analysis was done using ANOVA (Analysis of Variance). The statistically analysis of data pertaining to plant height $(\mathrm{cm})$, number of branches per plant, Number of leaves per plant, number of cluster per plant, seeds per pod, pod length, dry weight 
(g), Pods per plant, Pods per cluster and pod yield (g) was done to check significant differences observed among the treatments.

The Standard Error of the Mean (SEM) quantifies the precision of the mean. It is a measure of how far your sample mean is likely to be from the true population mean. It is expressed in the same units as the data. The coefficient of variation (CV), also known as "relative variability", equals the standard deviation divided by the mean. It can be expressed either as a fraction or a percent.

\section{Results and Discussion}

In all the observation aspects of growth and yield, the maximum value was recorded under bio-fertilizer treatment (T3) $9 \mathrm{gm}$ of Rhizobium leguminosarum +9 $\mathrm{gm}$ of phosphate solubilizing bacteria). But minimum value was found variably in different treatments and different observation aspects.

The average growth and yield per plot was found highest in T3 with germination count of 10 days, plant height $(48.34 \mathrm{~cm})$, no. of leaves per plant (28.83), no. of pods per plant (10), branches per plant (9.33), dry weight per plant (22.20 gm), no. of seeds per pod (7), pods per plant (10), pods per cluster (3), pod length $(15.23 \mathrm{~cm})$, pod yield (71.06 gm) and lowest in $\mathrm{T} 2$ (9 gm Rhizobium leguminosarum) having plant height $(34.16 \mathrm{~cm})$, no. of leaves per plant (21.25), no. of pods per plant (2.30), branches per plant (8.33), dry weight per plant (16.28 gm), no. of seeds per pod (4.33), pods per cluster (1.33), pod length $(10.45 \mathrm{~cm})$, pod yield (56.41 gm) respectively.

The morphological characters of different treatments are as: the number of days taken for germination was 8 days from the date of sowing (6/02/2015). Germination percentage was $85 \%$ in $\mathrm{T} 3$, which was the maximum percentage among all treatments.

Number of days taken for Flower initiation was 28 days in T2. Flower color was noted as creamish white in all treatments (Table 2).

The height of the plant was found to be highest in treatment three (T3) followed by treatment four (T4). The plant height was more in all the treatments as compared to (T2). The total number of branches was found to be highest in treatment three (T3) followed by treatment four (T4). The number of branches was more in all the treatments as compared to (T2) (Table 3).

The total number of leaves per plant was found to be highest in treatment three (T3) followed by treatment four (T4). The Dry weight of the plant was found to be highest in treatment three (T3) followed by treatment four (T4).

The number of Cluster per plant was found to be highest in treatment three (T3) followed by treatment four (T4). The number of Cluster per plant was more in all the treatments as compared to (T2).

The number of Pods per plant was found to be highest in Treatment three (T3) followed by Treatment four (T4). The number of Pods per plant was more in all the treatments as compared to (T2). The number of Pods per cluster was found to be highest in Treatment three (T3).

The Pod length was found to be highest in Treatment three (T3) followed by Treatment four (T4). The Pod yield was found to be highest in Treatment three (T3) followed by Treatment four (T4). The Pod yield was more in all the treatments as compared to (T2) (Table 4) (Fig. 1). 
Table.1 The experiment comprised of the following treatments

\begin{tabular}{|l|l|c|c|}
\hline Treatments & \multicolumn{1}{|c|}{ Material(s) used } & $\begin{array}{c}\text { N:P:K } \\
\text { (gm) }\end{array}$ & $\begin{array}{c}\text { Quantity } \\
\text { (gm) }\end{array}$ \\
\hline T1 (control) & \multicolumn{1}{|c|}{ N:P:K } & 9 & - \\
\hline T2 & $\begin{array}{l}\text { Rhizobium leguminosarum, N:P:K } \\
\text { T3 }\end{array}$ & $\begin{array}{l}\text { Rhizobium leguminosarum + phosphate } \\
\text { solubilizing bacteria (PSB)+ N:P:K }\end{array}$ & 9 \\
\hline T4 & $\begin{array}{l}\text { Rhizobium } \\
\text { leguminosarum+Pseudomonas }+N: P: K\end{array}$ & 9 & $9+9$ \\
\hline T5 & $\begin{array}{l}\text { Rhizobium leguminosarum + phosphate } \\
\text { solubilizing bacteria (PSB)+ } \\
\text { Pseudomonas }+\mathrm{N}: \mathrm{P}: \mathrm{K}\end{array}$ & 9 & $9+9+9$ \\
\hline
\end{tabular}

Table.2 Effect of different concentrations of biofertilizers on number of days for germination, percent germination and flower colour of Phaseolus vulgaris.

\begin{tabular}{|r|c|c|l|l|}
\hline Treatments & $\begin{array}{l}\text { No. of days for } \\
\text { germination }\end{array}$ & \% germination & Flower colour & $\begin{array}{l}\text { No. Of days } \\
\text { for flower } \\
\text { initiation }\end{array}$ \\
\hline $\mathrm{T}_{1}$ & 13 days & 45 & Creamy yellow & 41 \\
\hline $\mathrm{T}_{2}$ & 7 days & 66.6 & Creamy yellow & 28 \\
\hline $\mathrm{T}_{3}$ & 10 days & 85 & Creamy yellow & 31 \\
\hline $\mathrm{T}_{4}$ & 9 days & 72 & Creamy yellow & 37 \\
\hline $\mathrm{T}_{5}$ & 11 days & 63 & Creamy yellow & 39 \\
\hline
\end{tabular}

Table.3 Effect of different concentrations of biofertilizers on plant height, branches per plant, number of leaves per plant, dry weight of plant (g), and cluster per plant in Phaseolus vulgaris

\begin{tabular}{|c|c|c|c|c|c|c|}
\hline $\begin{array}{c}\text { S. } \\
\text { No }\end{array}$ & Treatments & $\begin{array}{c}\text { Plant height } \\
\text { (cm) }\end{array}$ & $\begin{array}{c}\text { Branches } \\
\text { per plant }\end{array}$ & $\begin{array}{c}\text { Number of leaves } \\
\text { per plant }\end{array}$ & $\begin{array}{c}\text { Dry weight of } \\
\text { the plant (g) }\end{array}$ & $\begin{array}{c}\text { Cluster } \\
\text { per } \\
\text { plant }\end{array}$ \\
\hline $\mathbf{1}$ & T1 (Control) & 37.50 & 8.66 & 23.08 & 17.95 & 2.33 \\
\hline $\mathbf{2}$ & $\mathbf{T 2}$ & 34.16 & 8.33 & 21.25 & 16.28 & 1.67 \\
\hline $\mathbf{3}$ & $\mathbf{T 3}$ & 48.34 & 9.33 & 28.83 & 22.20 & 3.73 \\
\hline $\mathbf{4}$ & $\mathbf{T 4}$ & 43.76 & 8.66 & 26.01 & 20.04 & 2.67 \\
\hline $\mathbf{5}$ & $\mathbf{T 5}$ & 40.13 & 8.33 & 24.23 & 19.29 & 2.67 \\
\hline & SEM $\mathbf{S}$ & 0.676 & 0.182 & 0.760 & 0.430 & 0.183 \\
\hline & $\mathbf{C D}$ & 2.878 & 3.648 & 5.455 & 3.891 & 12.483 \\
\hline & $\mathbf{C V}$ & 2.205 & 0.595 & 2.479 & 1.403 & 0.595 \\
\hline
\end{tabular}


Table.4 Effect of different concentrations of biofertilizers on pods per plant, pods per cluster, seeds per pod, pod length and pod yield in Phaseolus vulgaris.

\begin{tabular}{|c|c|c|c|c|c|c|}
\hline $\begin{array}{c}\text { S. } \\
\text { No }\end{array}$ & Treatments & $\begin{array}{c}\text { Pods per } \\
\text { plant }\end{array}$ & $\begin{array}{c}\text { Pods per } \\
\text { cluster }\end{array}$ & Seeds per pod & Pod Length & $\begin{array}{c}\text { Pod Yield } \\
\text { (g) }\end{array}$ \\
\hline $\mathbf{1}$ & $\mathbf{T 1}$ (Control) & 5.66 & 2.33 & 5.33 & 11.06 & 55.32 \\
\hline $\mathbf{2}$ & $\mathbf{T 2}$ & 2.30 & 1.33 & 4.33 & 10.45 & 56.41 \\
\hline $\mathbf{3}$ & $\mathbf{T 3}$ & 10.00 & 3.00 & 7 & 15.23 & 71.06 \\
\hline $\mathbf{4}$ & $\mathbf{T 4}$ & 6.33 & 2.33 & 6.33 & 14.46 & 69.33 \\
\hline $\mathbf{5}$ & $\mathbf{T 5}$ & 5.33 & 2.00 & 6.00 & 13.62 & 67.73 \\
\hline & SEM & 0.019 & 0.224 & 0.342 & 0.485 & 2.640 \\
\hline & $\mathbf{C D}$ & 29.754 & 17.604 & 10.200 & 6.481 & 7.148 \\
\hline & $\mathbf{C V}$ & 3.724 & 0.729 & 1.114 & 1.582 & 8.610 \\
\hline
\end{tabular}

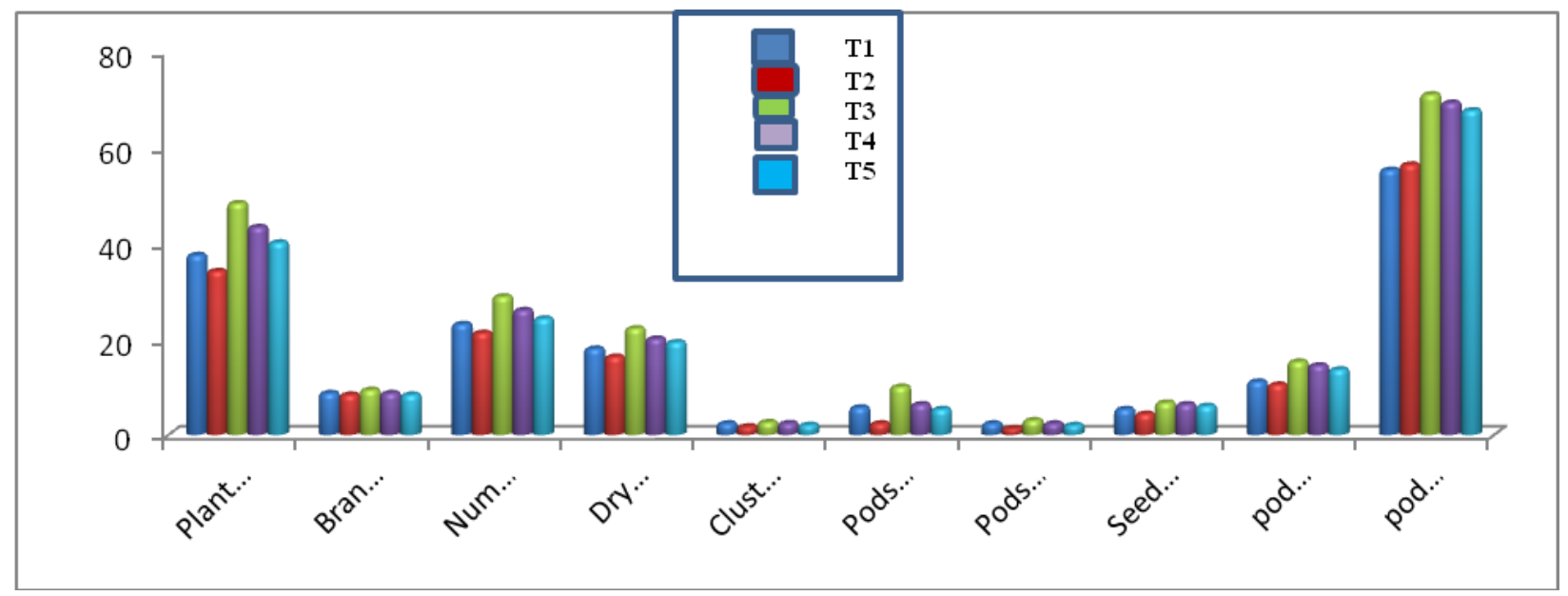

Fig.1 Effect of different concentrations of Biofertilizers on the plant

The results of the present study indicate that among the treatments soil application T3 (Treatment three) with nine grams of Rhizobium leguminosarum and nine grams of phosphate solubilizing bacteria (PSB) recorded increased plant height $(\mathrm{cm})$, number of branches per plant, Number of leaves per plant, number of cluster per plant, seeds per pod, pod length, dry weight (g), Pods per plant, Pods per cluster and pod yield (g).

The maximum plant height was $48.34 \mathrm{~cm}$, number of branches per plant was 9.33, Number of leaves per plant was 28.83, dry weight was $22.20 \mathrm{~g}$, number of cluster per plant was 3.73 , Pods per plant was 10.00,
Pods per cluster was 3.00 , seeds per pod was 7.00 , pod length was $15.23 \mathrm{~cm}$ and pod yield $71.06 \mathrm{~g}$ in treatment three (T3). The minimum plant height was $34.16 \mathrm{~cm}$, number of branches per plant was 9.33, Number of leaves per plant was 21.25 , dry weight was $16.28 \mathrm{~g}$, number of cluster per plant was 1.67 , Pods per plant was 2.30, Pods per cluster was 1.33 , seeds per pod was 4.33 , pod length was $10.45 \mathrm{~cm}$ and pod yield $56.41 \mathrm{~g}$ in treatment one (T1).

Hence the concentration of biofertilizers used in treatment three can be suggested to the farmers to increase the growth and yield of French bean. 
A field experiment was conducted at Department Of Plant Biotechnology, UAS, GKVK Campus, Bangalore to study the effect of various Concentrations of bio-fertilizers on growth, yield of French bean. The results revealed that the application of T2 significantly increased the plant height $(\mathrm{cm})$, number of branches per plant, leaf area $\left(\mathrm{cm}^{2}\right)$ and dry weight $(\mathrm{g})$ of plant in Arka anoop. The number of clusters per plant, number of pods per plant, number of pods per cluster, number of seeds per pod, pod length and pod yield per plant (g) was also significantly increased by the application of $\mathrm{T} 2$ as compared to control(T1) and other treatments (T3, T4, T5).

The results obtained from the investigation on the "Effect of different concentrations of biofertilizers on the growth and yield of French beans (Phaseolus vulgaris) arka anoop" by using different concentrations and types of biofertilizers on various treatments, treated with different compositions of biofertilizers on French beans. In the present study, efforts were made to screen, characterize selected french bean (arka anoop) accessions for their effect in the growth and yield of French bean. Thus the biofertilizer used and the its respective concentration can be used by the present farmers as a good source of French bean yield.

\section{Aknowledgement}

I would like to express my special thanks to Department of Plant Biotechnology, University of Agricultural Sciences, GKVK, Bangalore in helping me to complete my project within the limited time frame

\section{Competing Interests}

The authors declare that they have no competing interests

\section{Ethical Procedure}

As an expert scientist and along with coauthors of concerned field, the paper has been submitted with full responsibility, following due ethical procedure, and there is no duplicate publication, fraud, plagiarism, or concerns about animal or human experimentation.

\section{References}

Afzal MA, Murshad AN, Bakar MA, Hamid A, Salahuddin AB. Mungbean cultivation in Bangladesh. Pulse Research Centre, Bangladesh Agric. Res. Inst., Gazipur. 2008; 1701: 25.

Basu TK, Bandyopadhyay S. Effects of Rhizobium inoculation and nitrogen application on some yield attributes of moong. Environment and Ecology. 1990; 8(2): 650-4.

Board NI. The complete technology book on bio-fertilizer and organic farming. National Institute of Industrial Re; 2004 Oct 1.

Broughton WJ, Hernandez G, Blair M, Beebe S, Gepts P, Vanderleyden J. Beans (Phaseolus spp.)-model food legumes. Plant and soil. 2003 May 1; 252(1): 55128.

Kumar RP, Singh ON, Yogeshwar S, Sachchidanand D, Singh JP. Effect of integrated nutrient management on growth, yield, nutrient uptake and ecnomics of french bean (Phaseolus vulgaris). Indian Journal of Agricultural Sciences. 2009; 79(2): 122-8.

Oberson A, Bünemann EK, Friesen DK, Rao IM, Smithson PC, Turner BL, Frossard E. Improving phosphorus fertility in tropical soils through biological interventions. Marcel Dekker.

Pramanik JK, Chowdhury AS, Uddin FJ. Effect of biofertilizer and weeding on the growth characters and seed yield of 
summer mungbean. Journal of Environmental Science and Natural Resources. 2014; 7(1): 87-92.

Rao NS. Biofertilizers in agriculture. AA Balkema; 1982.

Sankhyan NK, Bhushan B, Sharma PK, Bhashan B. Effect of phosphorus, mulch and farmyard manure on soil moisture and productivity of maize in mid hills of Himachal Pradesh. Res. on Crops. 2001; 2: 116-9.

Satti AA, Elnasikh MH, Elamin AY, Nasr

OE, Salih SM. Evaluation of some organic materials and a biofertilizer on different aspects of Snap Bean (Phaseolus vulgaris L.) under heavy soil of Sudan. Agriculture and Biology Journal of North America. 2010; 1(4): 541-7.

Singh NI, Chauhan JS. Response of French bean (Phaseolus vulgaris L.) to organic manures and inorganic fertilizer on growth and yield parameters under irrigated condition. Nature and Science. 2009; 7(5): 52-4.

\section{How to cite this article:}

Madhvi Sharma, Kodihally Manchegowda Harinikumar and Anil Kumar Singh. 2020. Effect of Different Concentrations of Biofertilizers on the Growth and Yield of French Bean (Phaseolus vulgaris) Arka Anoop. Int.J.Curr.Microbiol.App.Sci. 9(04): 3072-3078.

doi: https://doi.org/10.20546/ijcmas.2020.904.358 